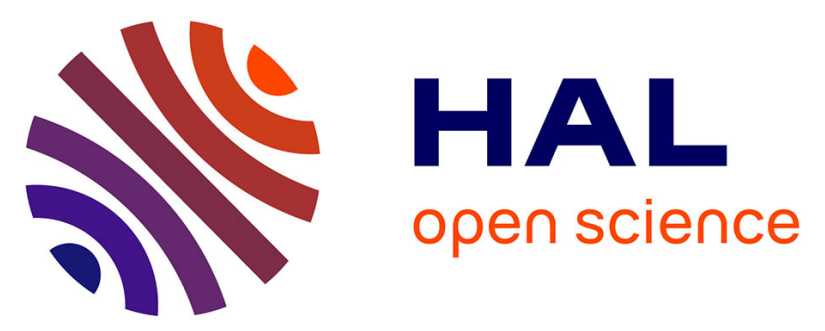

\title{
Seasonal variations of exposure biomarkers, oxidative stress responses and cell damage in the clams, and mussels, , from Adriatic sea
}

Raffaella Bocchetti, Claudia Virno Lamberti, Barbara Pisanelli, Erika M. Razzetti, Chiara Maggi, Barbara Catalano, Giulio Sesta, Giacomo Martuccio, Massimo Gabellini, Francesco Regoli

\section{To cite this version:}

Raffaella Bocchetti, Claudia Virno Lamberti, Barbara Pisanelli, Erika M. Razzetti, Chiara Maggi, et al.. Seasonal variations of exposure biomarkers, oxidative stress responses and cell damage in the clams, , and mussels, , from Adriatic sea. Marine Environmental Research, 2008, 66 (1), pp.24. 10.1016/j.marenvres.2008.02.013 . hal-00501942

\section{HAL Id: hal-00501942 https://hal.science/hal-00501942}

Submitted on 13 Jul 2010

HAL is a multi-disciplinary open access archive for the deposit and dissemination of scientific research documents, whether they are published or not. The documents may come from teaching and research institutions in France or abroad, or from public or private research centers.
L'archive ouverte pluridisciplinaire HAL, est destinée au dépôt et à la diffusion de documents scientifiques de niveau recherche, publiés ou non, émanant des établissements d'enseignement et de recherche français ou étrangers, des laboratoires publics ou privés. 


\section{Accepted Manuscript}

Seasonal variations of exposure biomarkers, oxidative stress responses and cell damage in the clams, Tapes philippinarum, and mussels, Mytilus galloprovincialis, from Adriatic sea

Raffaella Bocchetti, Claudia Virno Lamberti, Barbara Pisanelli, Erika M.

Razzetti, Chiara Maggi, Barbara Catalano, Giulio Sesta, Giacomo Martuccio, Massimo Gabellini, Francesco Regoli

PII:

S0141-1136(08)00029-9

DOI: 10.1016/j.marenvres.2008.02.013

Reference: $\quad$ MERE 3181

To appear in: $\quad$ Marine Environmental Research

Please cite this article as: Bocchetti, R., Lamberti, C.V., Pisanelli, B., Razzetti, E.M., Maggi, C., Catalano, B., Sesta, G., Martuccio, G., Gabellini, M., Regoli, F., Seasonal variations of exposure biomarkers, oxidative stress responses and cell damage in the clams, Tapes philippinarum, and mussels, Mytilus galloprovincialis, from Adriatic sea, Marine Environmental Research (2008), doi: 10.1016/j.marenvres.2008.02.013

This is a PDF file of an unedited manuscript that has been accepted for publication. As a service to our customers we are providing this early version of the manuscript. The manuscript will undergo copyediting, typesetting, and review of the resulting proof before it is published in its final form. Please note that during the production process errors may be discovered which could affect the content, and all legal disclaimers that apply to the journal pertain. 
Seasonal variations of exposure biomarkers, oxidative stress responses and cell damage in the clams, Tapes philippinarum, and mussels, Mytilus galloprovincialis, from Adriatic sea

\author{
Raffaella Bocchetti ${ }^{\text {a }}$, Claudia Virno Lamberti ${ }^{\text {b }}$, Barbara Pisanelli ${ }^{\text {a }}$, Erika M. \\ Razzetti $^{1}$, Chiara Maggi ${ }^{\text {b }}$, Barbara Catalano ${ }^{\text {b }}$, Giulio Sesta ${ }^{\text {b }}$,Giacomo \\ Martuccio $^{\text {a }}$, Massimo Gabellini ${ }^{\text {b }}$, Francesco Regoli ${ }^{\text {a, }}$ \\ ${ }^{a}$ Istituto di Biologia e Genetica, Università Politecnica delle Marche, Ancona, Italia and \\ ${ }^{b}$ ICRAM, Istituto Centrale per la Ricerca Scientifica e Tecnologica Applicata al Mare (Roma)
}

\begin{abstract}
This work investigated the natural variability of several biomarkers in Tapes philippinarum and Mytilus galloprovincialis, sampled from Northern Adriatic where these organisms are important sentinel species for future environmental impact assessment. Levels of metallothioneins, peroxisomal enzymes and acetylcholinesterase, showed a significant seasonality and marked differences between clams and mussels. Among antioxidant enzymes, catalase and GST decreased during the warmer period, the latter enzyme activity resulting particularly high in clams. The total oxyradical scavenging capacity toward peroxyl radicals decreased in mussels from winter to summer, indicating a prooxidant challenge due to higher seawater temperature and intensity of light irradiance. Lysosomal membrane stability did not exhibit significant seasonal variations, while some variations were observed for DNA damages. Overall results indicated a significant influence
\end{abstract}


of seasonal variability on several biomarkers and species-specific differences which should be considered to discriminate the appearance of anthropogenic disturbance.

Keywords: Seasonality; Tapes philippinarum; Mytilus galloprovincialis; Biomarkers; Oxidative stress

*Corresponding author: Via Ranieri (Montedago) 65, 60131-Ancona, Italy. Tel: +390712204142;

Fax: +390712204609

E-mail address: f.regoli@ univpm.it (F. Regoli) 
Biomarkers are important tools for revealing biological effects of contaminants in marine organisms. However, such biological responses can be influenced by natural factors and this basal variability needs to be distinguished by the effects caused by pollutants. The aim of this work was to investigate the seasonal fluctuations of a battery of biomarkers in a wild population of clams (Tapes philippinarum) and mussels (Mytilus galloprovincialis) sampled from a brackish environment in Northern Adriatic, characterized by the presence of aquaculture farms and selected for future installation of an energy plants. Metallothioneins, peroxisomal enzymes (acyl CoA oxidase) and activity of acetylcholinesterase were measured as specific exposure responses toward trace metals, organic chemicals and organophosphates pesticides, respectively. Due to the high importance of oxyradicals in mediating the effects of pollutants, oxidative status of the organisms was evaluated by the analyses of individual antioxidants, catalase (CAT), glutathione S-transferases (GST), glutathione reductase (GR), Se-dependent and Se-independent glutathione peroxidases (GPx), levels of total glutathione (TGSH); the overall susceptibility to oxidative stress conditions was further evaluated through the total oxyradical scavenging capacity (TOSC) which quantify the whole capability of tissues to neutralize different forms of oxyradicals (Gorbi and Regoli, 2003). At subcellular level, lysosomal membrane stability (LMS) and DNA integrity were measured as targets of oxidative and chemical toxicity.

Specimens of T. philippinarum and M. galloprovincialis were collected on a seasonal basis and digestive glands rapidly dissected; for each sampling period and species, 10 samples were prepared (each constituted by tissues of 5 specimens), frozen in liquid nitrogen and stored at $-80^{\circ} \mathrm{C}$. Haemolymph collected from ten specimens was immediately processed for LMS and DNA integrity. Metallothioneins-like proteins (MTSH), acyl CoA oxidase (AOX), acetylcholinesterase (AChE) and individual antioxidants (CAT, GST, GR, GPx and TGSH) were determined by specific spectrophotometric assays (Bocchetti and Regoli, 2006); TOSC toward peroxyl and hydroxyl radicals by gas chromatographic analyses (Regoli and Winston, 1999); lysosomal membrane stability by neutral red retention time (Lowe and Pipe, 1994); loss of DNA integrity by the comet 
assay and frequency of micronuclei (Venier et al., 1996; Machella et al., 2006). Data were analyzed by two-way analyses of variance (ANOVA) and principal component analyses (PCA) to test differences between sampling periods and species.

Analyses of trace metals and PAHs performed in a parallel study did not reveal evidence of chemical contamination while biomarkers showed significant differences as a function of sampling period and species (Table 1). Metallothioneins-like proteins in clams were higher in winter and spring confirming the sensitivity of this parameter to biological factors like reproductive cycle; similar or slightly lower values were measured in mussels. Activity of AOX in clams showed limited seasonal variations, while mussels exhibited a ten folds difference between winter and summer values; this effect can reflect the lower food content available for mussels in water column during the summer, and a resulting decrease of AOX-mediated oxidation of fatty acids. Acetylcholinesterase was higher in both the species during the autumn, and then progressively decreased toward the summer period, confirming a seasonal trend already reported for Adriatic mussels (Bocchetti and Regoli, 2006). The comparison between species revealed markedly lower AChE activities in clams which, beside a physiological reason, could also indicate the preference for a different substrate during the assay.

Among oxidative responses, CAT, GST and GPx exhibited the lowest values in both the species during the summer and such effects were also reflected by lower TOSC values toward peroxyl radicals in M. galloprovincialis; summer variations of antioxidant efficiency have been indicated in several Mediterranean organisms as a typical short-term response to the seasonal increase of prooxidant challenge due to higher seawater temperature and intensity of light irradiance (Regoli et al., 2004). Species differences were particularly evident for GST with higher activities in clams potentially suggesting the influence of a different diet composition in this sedimentassociated bivalve; the presence of GST substrates in sediments has already been hypothesized in scallops to explain the exceptionally high activities of such enzymes in these bivalves with a sediment-dwelling feeding strategy (Regoli et al., 1997). 
Lysosomal stability showed fluctuating variations indicating a certain biological disturbance and resulting always significantly lower in clams, as a specific characteristic of this species. DNA fragmentation was generally comparable in the two species, with the exception of summer period when the highest and lowest values were measured respectively for clams and mussels; frequency of micronuclei was more variable in clams than in mussels, but values, always within $0.5 \%$, are quite typical for control organisms.

The treatment of overall data by PCA indicated a clear separation of various sampling periods for both the species and a marked difference between these organisms (Fig. 1). A more evident effect of seasonality was observed for mussels especially during the summer period; these results indicate mussels as more influenced by the greater seasonal variations of environmental factors (i.e. seawater temperature and food availability) in water column, compared to those experienced by sediment-associated species. In conclusion, this study confirmed a marked seasonality of several biological parameters normally used as biomarkers and species-specific differences in organisms with different trophic strategies and/or ecological habits: such natural variability should be adequately considered when biomarkers' responses are interpreted to detect anthropogenic disturbance. 


\section{ACCEPTED MANUSCRIPT}

\section{References}

Bocchetti, R., and Regoli, F. (2006). Chemosphere, 65, 913-921.

Gorbi, S., and Regoli, F. (2003). Comments on Toxicology, 9, 303-322.

Lowe, D.M., and Pipe, R.K. (1994). Aquatic Toxicology, 30, 357-365.

Machella, N., Battino, M., Pisanelli, B., and Regoli, F. (2006). Environmental and Molecular Mutagenesis, 47, 579-586.

Regoli, F., Principato, G., Bertoli, E., Nigro, M., and Orlando, E. (1997). Polar Biology, 17, 251258.

Regoli, F., and Winston, G.W. (1999). Toxicology and Applied Pharmacology, 156, 96-105.

Regoli, F., Cerrano, C., Chierici, E., Chiantore, M.C., and Bavestrello, G. (2004). Marine Ecology Progress Series, 275, 129-137.

Venier, P., Maron, S., and Canova, S. (1997). Mutation Research/Genetic Toxicology and Environmental Mutagenesis, 390, 33-44. 


\section{ACCEPTED MANUSCRIPT}

\section{Figure caption:}

Fig. 1: Separation of species and periods obtained by Principal Component Analysis (PCA) of biological responses measured in mussels and clams during the four seasonal samplings. 


\section{ACCEPTED MANUSCRIPT}

Factor $2(21 \%)$

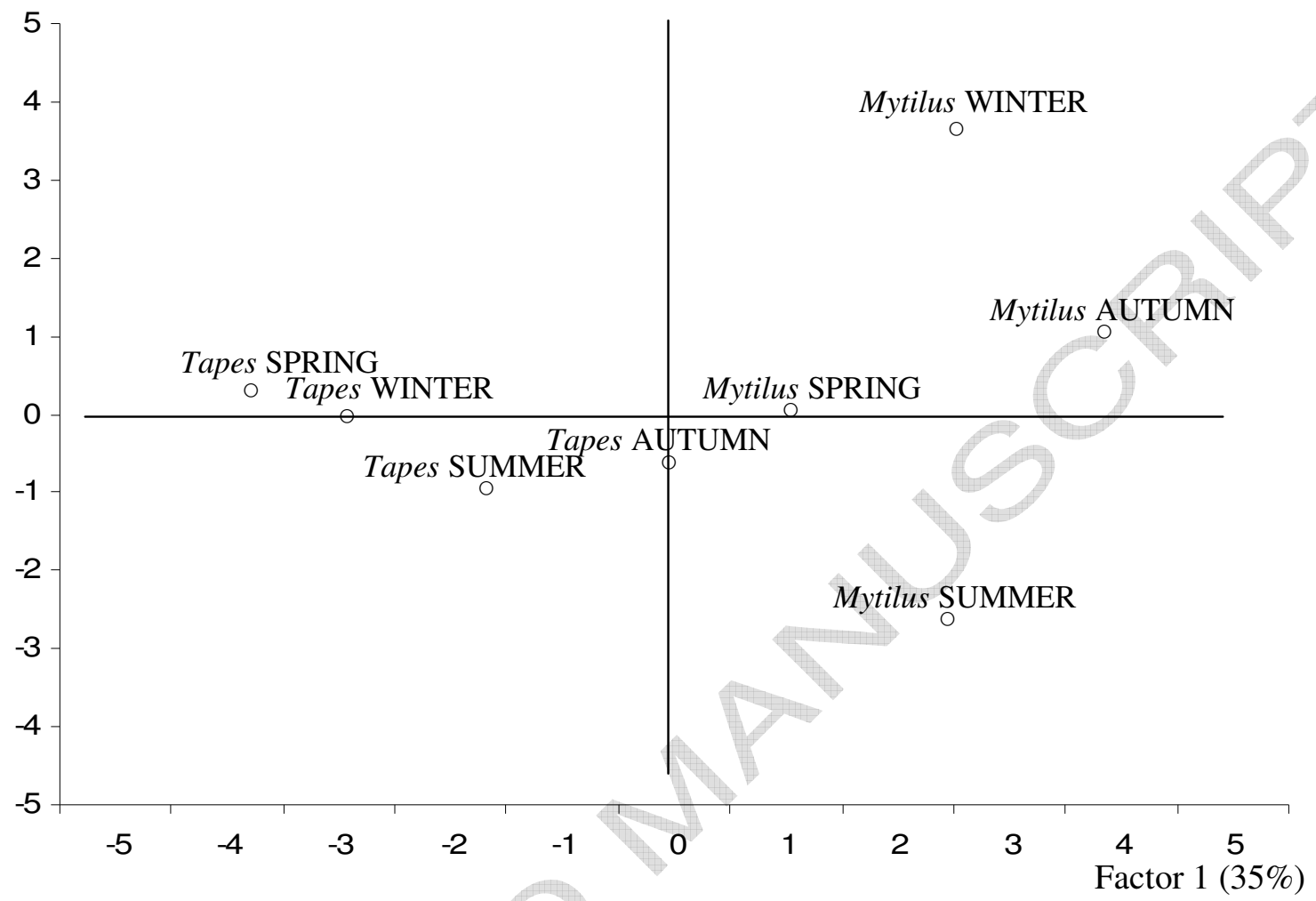

Figure 1 
Table 1.

Seasonal variations of biomarkers (mean values \pm standard deviations, $\mathrm{n}=10$ ) in clams (Tapes philippinarum, TP) and mussels (Mytilus galloprovincialis, MG). MTSH: metallothioneins like proteins (Eq. GSH nmol/mg prt); AOX: acetyl CoA oxidase (nmol/min/mg prt); AChE: acetylcholinesterase (nmol/min/mg prt), CAT: catalase ( $\mu \mathrm{mol} / \mathrm{min} / \mathrm{mg} \mathrm{prt})$; GST: glutathione Stransferases (nmol/min/mg prt); GR: glutathione reductase (nmol/min/mg prt); GPx: glutathione peroxidases (nmol/min/mg prt); TGSH: total glutathione ( $\mu \mathrm{mol} / \mathrm{g}$ tiss); ROO• and HO•: TOSC toward peroxyl and hydroxyl radicals (UTosc/mg prt), LMS: lysosomal membrane stability (min), DNA: \% of DNA damage; MN: \%o frequency of micronuclei. Different letters indicate significant differences between seasonal samplings, while asterisks indicate significant differences between clams and mussels (two ways ANOVA and post hoc comparison); the $p$ values are given for the interaction "season x species" only when both these 2 factors resulted statistically significant.

\begin{tabular}{|c|c|c|c|c|c|c|c|c|c|c|}
\hline & & \multicolumn{2}{|c|}{ Autumn } & \multicolumn{2}{|l|}{ Winter } & \multicolumn{2}{|l|}{ Spring } & \multicolumn{2}{|c|}{ Summer } & \multirow{2}{*}{$\begin{array}{c}\text { Season } \\
\mathrm{X} \\
\text { species }\end{array}$} \\
\hline & & Mean & s.d. & Mean & s.d. & Mean & s.d. & Mean & s.d. & \\
\hline MTSH & $\begin{array}{l}T P \\
M G\end{array}$ & $\begin{array}{l}2.47^{\mathrm{a}} \\
3.64^{\mathrm{a}}\end{array}$ & $\begin{array}{l}0.18 \\
0.15\end{array}$ & $\begin{array}{l}5.09^{\mathrm{b}} \\
3.39^{\mathrm{a}} *\end{array}$ & $\begin{array}{l}1.03 \\
0.64\end{array}$ & $\begin{array}{l}5.79^{\mathrm{b}} \\
2.11^{\mathrm{ab}} *\end{array}$ & $\begin{array}{l}0.56 \\
0.04\end{array}$ & $\begin{array}{l}2.68^{\mathrm{a}} \\
1.29^{\mathrm{b}} *\end{array}$ & $\begin{array}{l}0.12 \\
0.23\end{array}$ & $p<0.05$ \\
\hline AOX & $\begin{array}{l}T P \\
M G\end{array}$ & $\begin{array}{l}0.82 \\
0.63^{\mathrm{a}}\end{array}$ & $\begin{array}{l}0.13 \\
0.04\end{array}$ & $\begin{array}{l}1.03 \\
1.93^{\mathrm{b}} *\end{array}$ & $\begin{array}{l}0.29 \\
0.38\end{array}$ & $\begin{array}{l}1.08 \\
0.95^{\mathrm{a}}\end{array}$ & $\begin{array}{l}0.12 \\
0.13\end{array}$ & $\begin{array}{l}0.89 \\
0.16^{\mathrm{c}} *\end{array}$ & $\begin{array}{l}0.09 \\
0.07\end{array}$ & \\
\hline $\mathbf{A C H}$ & $\begin{array}{l}T P \\
M G\end{array}$ & $\begin{array}{l}16.8 \\
191^{a} *\end{array}$ & $\begin{array}{l}5.10 \\
2.39\end{array}$ & $\begin{array}{l}14.9 \\
96.8^{\mathrm{b}} *\end{array}$ & $\begin{array}{l}2.75 \\
30.7\end{array}$ & $\begin{array}{l}12.6 \\
89.7^{\mathrm{b}} *\end{array}$ & $\begin{array}{l}2.33 \\
13.4\end{array}$ & $\begin{array}{l}11.4 \\
60.5^{\mathrm{c}} *\end{array}$ & $\begin{array}{l}5.02 \\
20.5\end{array}$ & $p<0.000001$ \\
\hline CAT & $\begin{array}{l}T P \\
M G\end{array}$ & $\begin{array}{l}31.6^{\mathrm{a}} \\
22.8^{\mathrm{a}} *\end{array}$ & $\begin{array}{l}3.01 \\
0.95\end{array}$ & $\begin{array}{l}40.8^{\mathrm{b}} \\
21.2^{\mathrm{a}} *\end{array}$ & $\begin{array}{l}3.57 \\
1.74\end{array}$ & $\begin{array}{l}38.8^{\mathrm{b}} \\
12.9^{\mathrm{b}} *\end{array}$ & $\begin{array}{l}5.28 \\
1.56\end{array}$ & $\begin{array}{l}24.5^{\mathrm{c}} \\
3.34^{\mathrm{c}} *\end{array}$ & $\begin{array}{l}5.86 \\
0.09\end{array}$ & $p<0.05$ \\
\hline GST & $\begin{array}{l}T P \\
M G\end{array}$ & $\begin{array}{l}285^{\mathrm{a}} \\
171\end{array}$ & $\begin{array}{l}62 \\
37.6\end{array}$ & $\begin{array}{l}1276^{\mathrm{b}} \\
137^{*}\end{array}$ & $\begin{array}{l}261 \\
17.3\end{array}$ & $\begin{array}{l}863^{c} \\
112^{*}\end{array}$ & $\begin{array}{l}228 \\
6.75\end{array}$ & $\begin{array}{l}439^{\mathrm{a}} \\
64.8^{*}\end{array}$ & $\begin{array}{l}162 \\
13.6\end{array}$ & $p<0.000001$ \\
\hline GR & $\begin{array}{l}T P \\
M G\end{array}$ & $\begin{array}{c}29.8^{\mathrm{a}} \\
21.5\end{array}$ & $\begin{array}{l}3.38 \\
1.97\end{array}$ & $\begin{array}{l}39.5^{\mathrm{b}} \\
24.3^{*}\end{array}$ & $\begin{array}{l}3.81 \\
5.53\end{array}$ & $\begin{array}{l}32.8^{\mathrm{ab}} \\
16.9^{*}\end{array}$ & $\begin{array}{l}2.94 \\
2.28\end{array}$ & $\begin{array}{l}37.6^{\mathrm{b}} \\
16.4^{*}\end{array}$ & $\begin{array}{l}2.45 \\
1.96\end{array}$ & $p>0.05$ \\
\hline GPx & $\begin{array}{l}T P \\
M G\end{array}$ & $\begin{array}{l}13.7^{\mathrm{ab}} \\
17.1^{\mathrm{a}}\end{array}$ & $\begin{array}{l}1.99 \\
2.05\end{array}$ & $\begin{array}{l}9.86^{\mathrm{ac}} \\
14.2^{\mathrm{ab}}\end{array}$ & $\begin{array}{l}2.86 \\
0.84\end{array}$ & $\begin{array}{l}15.2^{\mathrm{b}} \\
11.4^{\mathrm{b}}\end{array}$ & $\begin{array}{l}3.72 \\
0.86\end{array}$ & $\begin{array}{l}8.53^{\mathrm{c}} \\
3.15^{\mathrm{c}} *\end{array}$ & $\begin{array}{l}1.44 \\
0.69\end{array}$ & \\
\hline TGSH & $\begin{array}{l}T P \\
M G\end{array}$ & $\begin{array}{l}0.66^{\mathrm{ab}} \\
0.97^{\mathrm{ab}} *\end{array}$ & $\begin{array}{l}0.07 \\
0.07\end{array}$ & $\begin{array}{l}0.84^{b} \\
0.67^{b}\end{array}$ & $\begin{array}{l}0.15 \\
0.16\end{array}$ & $\begin{array}{l}0.44^{\mathrm{a}} \\
0.87^{\mathrm{ab}} *\end{array}$ & $\begin{array}{l}0.07 \\
0.05\end{array}$ & $\begin{array}{l}0.64^{\mathrm{ab}} \\
0.79^{\mathrm{ab}}\end{array}$ & $\begin{array}{l}0.13 \\
0.16\end{array}$ & \\
\hline ROO• & $\begin{array}{l}T P \\
M G\end{array}$ & $\begin{array}{l}368^{a} \\
451^{a}\end{array}$ & $\begin{array}{l}39.9 \\
112\end{array}$ & $\begin{array}{l}526^{\mathrm{b}} \\
612^{\mathrm{b}}\end{array}$ & $\begin{array}{l}169 \\
94.8\end{array}$ & $\begin{array}{l}560^{\mathrm{b}} \\
631^{\mathrm{b}}\end{array}$ & $\begin{array}{l}114 \\
34.8\end{array}$ & $\begin{array}{l}528^{\mathrm{b}} \\
314^{\mathrm{a}} *\end{array}$ & $\begin{array}{l}124 \\
74.8\end{array}$ & \\
\hline HO• & $\begin{array}{l}T P \\
M G\end{array}$ & $\begin{array}{l}233^{\mathrm{a}} \\
278^{\mathrm{a}}\end{array}$ & $\begin{array}{l}60.0 \\
59.5\end{array}$ & $\begin{array}{l}366^{\mathrm{b}} \\
333^{\mathrm{ab}} *\end{array}$ & $\begin{array}{l}75.0 \\
22.5\end{array}$ & $\begin{array}{l}431^{b} \\
403^{b} *\end{array}$ & $\begin{array}{l}75.4 \\
3.09\end{array}$ & $\begin{array}{l}388^{b} \\
303^{a b}\end{array}$ & $\begin{array}{l}31.4 \\
110\end{array}$ & $p>0.05$ \\
\hline LMS & $\begin{array}{l}T P \\
M G\end{array}$ & $\begin{array}{l}11.0 \\
41.3^{\mathrm{a}} *\end{array}$ & $\begin{array}{l}3.06 \\
8.31\end{array}$ & $\begin{array}{l}8.59 \\
25.5^{\mathrm{b}} *\end{array}$ & $\begin{array}{l}2.91 \\
7.79\end{array}$ & $\begin{array}{l}8.00 \\
44.1^{\mathrm{a}} *\end{array}$ & $\begin{array}{l}1.00 \\
10.1\end{array}$ & $\begin{array}{l}16.9 \\
38.3^{\mathrm{a}} *\end{array}$ & $\begin{array}{l}5.94 \\
16.5\end{array}$ & $p<0.05$ \\
\hline DNA & $\begin{array}{l}T P \\
M G\end{array}$ & $\begin{array}{l}37.6^{\mathrm{a}} \\
26.2^{\mathrm{a}} *\end{array}$ & $\begin{array}{l}10.0 \\
4.30\end{array}$ & $\begin{array}{l}42.7^{\mathrm{ab}} \\
44.4^{\mathrm{b}}\end{array}$ & $\begin{array}{l}3.38 \\
10.3\end{array}$ & $\begin{array}{l}49.0^{\mathrm{ab}} \\
49.8^{\mathrm{b}}\end{array}$ & $\begin{array}{l}3.46 \\
9.29\end{array}$ & $\begin{array}{l}52.0^{\mathrm{b}} \\
27.7^{\mathrm{a}} *\end{array}$ & $\begin{array}{l}9.84 \\
1.98\end{array}$ & $p<0.000001$ \\
\hline MN & $\begin{array}{l}T P \\
M G\end{array}$ & $\begin{array}{c}0.40 \\
0.40\end{array}$ & $\begin{array}{l}0.28 \\
0.14\end{array}$ & $\begin{array}{l}0.05 \\
0.50^{*}\end{array}$ & $\begin{array}{l}0.01 \\
0.14\end{array}$ & $\begin{array}{l}0.15 \\
0.40\end{array}$ & $\begin{array}{l}0.13 \\
0.14\end{array}$ & $\begin{array}{l}0.35 \\
0.20\end{array}$ & $\begin{array}{l}0.30 \\
0.14\end{array}$ & \\
\hline
\end{tabular}

